\title{
妊娠・分婏時のプレカリクレイン，カリクレイン 動態について
}

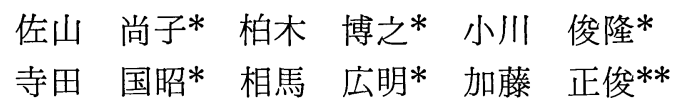

\section{Circulating levels of prekallikrein and kallikrein in pregnancy and labor}

\author{
Shoko SAYAMA*, Hiroyuki KASHIWAGI*, Toshitaka OGAWA*, \\ Kuniaki TERADA*, Hiroaki SOMA* and Masatoshi KATO**
}

Key words : prekallikrein, kallikrein, fibrinolytic inhibitors, pregnancy, labor

Plasma levels of prekallikrein and kallikrein in pregnancy and labor have been measured by the chromogenic substrate, S-2302. At the same time, fibrinolytic inhibitors such as $\alpha_{1}$-AT, $\alpha_{2}$-MG, AT III and Cl-inactivator as well as $\alpha_{2}$-PI were determined by a radial immunodiffusion method.

1) Levels of plasma prekallikrein in normal pregnancy were significantly greater than those in non-pregnant state, and the mean prekallikrein level at 42 weeks of gestation was $201 \pm 22.12 \%$, thereafter it decreased to $104 \pm 20.2 \%$ within 30 minutes after delivery. Prekallikrein levels in uterine blood were significantly higher than those in cord blood as well as retroplacental blood.

2) Plasma kallikrein concentrations in normal pregnancy were within nonpregnant levels until 42 weeks of gestation, but the level increased to $35.33 \pm$ $10.12 \%$ just before delivery and after delivery it raised to $65.33 \pm 13.22 \%$.

3) The mean prekallikrein titer in twin pregnancy was $121.33 \pm 26.1 \%$, whereas in cases with severe toxemia and hydatidiform mole, the levels were $68 \pm 8.96 \%$ and $77.16 \pm 28.1 \%$, respectively.

4) After $\mathrm{Cl}$-inactivator concentration showed over $20 \mathrm{mg} / \mathrm{dl}$ in early pregnancy, it dropped below $20 \mathrm{mg} / \mathrm{dl}$ until 40 weeks of gestation.

Therefore, it was suggested that circulating plasma prekallikrein and kallikrein system can work on the mechanism of labor pain and coagulation and fibrinolytic activity taking place in the utero-placental circulation.

* 東京医科大学産婦人科 〔干160 東京都新宿区西新宿6-7-1], Department of Obstetrics and Gynecology, Tokyo Medical College, Tokyo, Japan.

** 同 臨床病理, Department of Clinical Pathology, Tokyo Medical College, Tokyo, Japan. 
目的

妊娠分婏時には，各種ホルモンの影響のみな らず，妊張時には各凝固因子の増量, 線溶抑制 状態がみられ，血栓化傾向にあるといわれる ${ }^{1)}$.

一方娃娠後期には, 陣痛発来関係するキニ ン産生や $\mathrm{PgF}_{2} \alpha$ の急增むみられる。 その他, 重症妊娠中毒症や胎盤剝離異常, 胞状奇胎など の異常妊娠時には，DICを併発しやすいといわ れる ${ }^{2}$. そのためこれら基儊疾患時の凝固・線 溶系の動きを知るために，内因系の凝固や線溶 系およびキニン系にす始動するとみられるプレ カリクレイン・カリクレイン系の正常・異常妊 娠分婏時の動態を知るとと屯に分娩時の子宮 · 胎盤間の局所的な動態をむ測定することにし た。

\section{I. 研究方法}

対象には，非妊婦血15例，妊娠 147 例，分婏 前後母体血10例，胎盤胎児面血，臍帯血，胎盤 後血, 子宮静脈血, 双胎妊娠, 妊娠中毒症, 胞 状奇胎患者血漿招よび羊水を採取し，遠心分離 後, 使用した.

プレカリクレイン，カリクレインは，発色性 合成ペプチド基質 S-2302 を用いて測定した ${ }^{3)}$. その際の第X因子の活性には，七ホテストを用
いた．また羊水中のプレカリクレイン，カリク レインの測定には，血漿 1 : 羊水 1 の割合に混 合して測定した。

線溶インヒビターである $\alpha_{2}$ - PI, AT- III， Ci-INA， $\alpha_{1}$-AT については，一元免疫拡散法 を用い測定した。

\section{II. 成 績}

1）正常妊娠時に扰けるプレカリクレイン值 は，妊娠初期からかなりの増量傾向にある（図 1). ことに妊娠 42 週では $201 \pm 22.12 \%$ となり， 非妊婦の $110 \pm 28.9 \%$ よりはるかに増量を示し たが，分婏直前には，189土21.86\%と低下し， 分婏30分後には， $104 \pm 20.21 \%$ 之約 1/2 の減少 を示した。

カリクレイン值は, 妊娠時多少の変動はあっ てむ, 非妊婦 $19.8 \pm 18.9 \%$ の正常範囲内を維持 し，妊娠42週でも $26.67 \pm 8.76 \%$ と正常範囲内 にあった，しかし分婏直前には，35. $33 \pm 10.12$ \%とやや増量を示し，分婏後 30 分では， 65.33 土13.33\%と急增した。

2）双胎妊娠時のプレカリクレイン平均值は $121.33 \pm 26.1 \%$ ，切迫流産は，79土18.8\% 之低 く重症妊娠中毒症では, $68 \pm 8.9 \%$ とさらに低 值を示した。また胞状奇胎婏出時では，77.16 $\pm 28.1 \%$ と低值を示した（図 2).

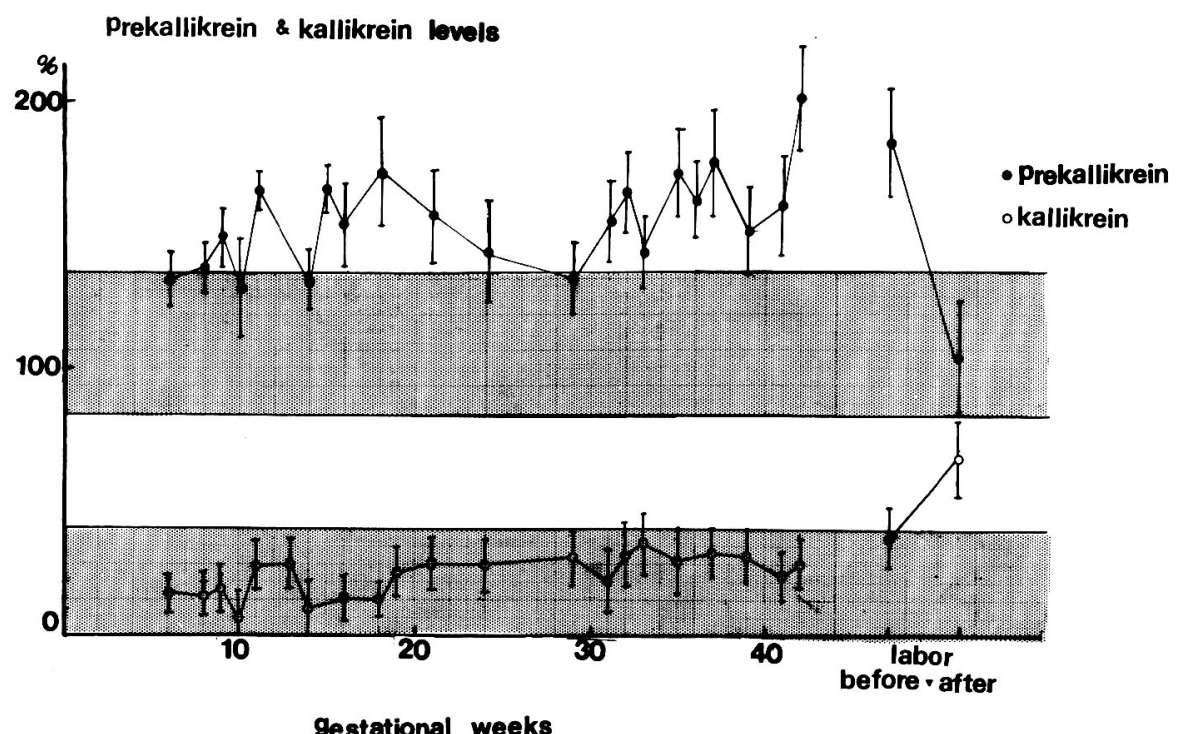

Fig. 1 Plasma levels of prekallikrein and kallikrein during pregnancy and delivery 


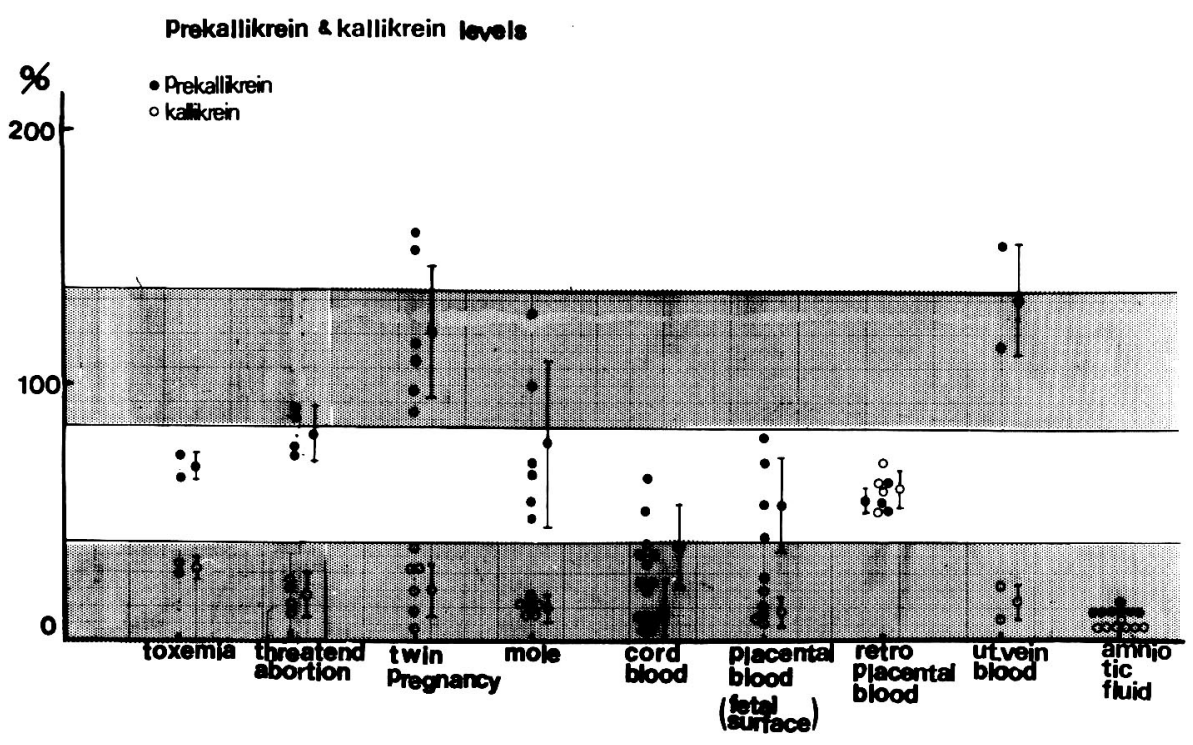

Fig. 2 The concentrations of prekallikrein and kallikrein in utero-placental blood and in complicated pregnancy.

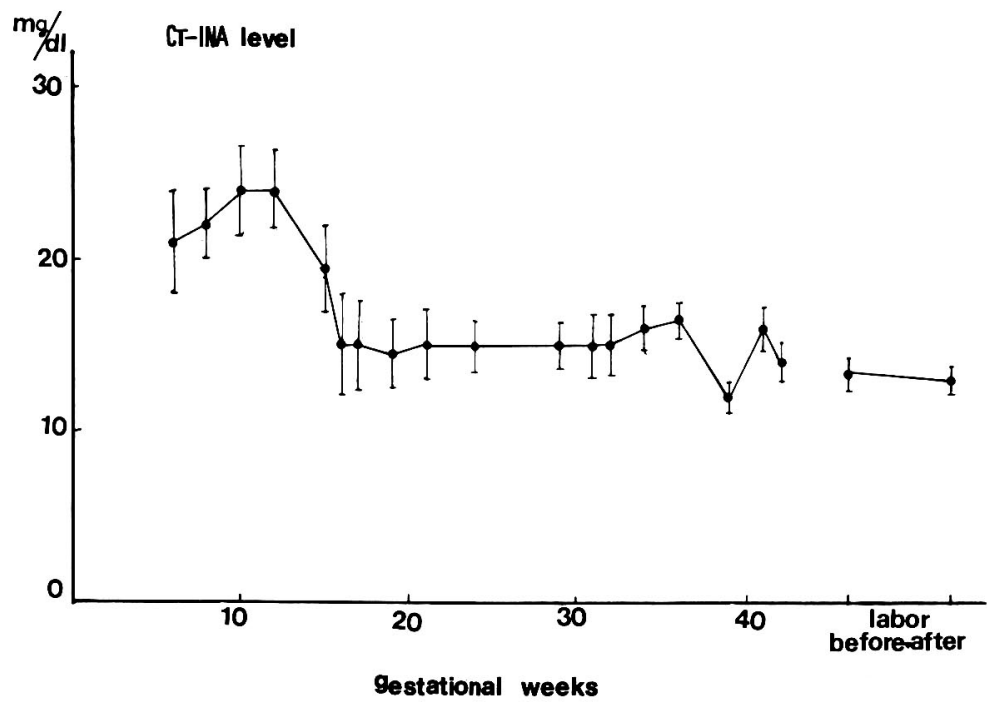

Fig. $3 \mathrm{Cl}$-inactivator levels in pregnancy

一方，子宮静脈血のプレカリクレイン值は， 136. $5 \pm 21.5 \%$ と高值を示すのに対し，臍帯血 值 $37.4 \pm 14.4 \%$ ，胎盤 胎览面血值 $54.2 \pm 19.4$ $\%$, 胎盤後血値 $55.3 \pm 4.98 \%$ と低值であり, 羊 水值は極めて低かった。 カリクレイン值は, 双 胎例での $21.33 \pm 10.52 \%$ に比して, 胞状奇胎, 臍带血, 胎盤血, 子宮静脈血, 羊水之も正常範 囲内の低值を示したが，胎盤後血のみ $60 \pm 6.4$ \%と高值を示した（図 2 ）。
3）妊娠分婏時の $\alpha_{2}$-PI 值は，妊娠中ほぼ同 様のレベルにあり，妊娠末期にはやや減少し分 婏時には低下を示した。 $\alpha_{1}$-AT值は，正常值の $220 \pm 49 \mathrm{mg} / \mathrm{d} l$ よりやや高值を示し，分婏時や や減量した。AT- III 值は妊娠 8 週では $45 \pm 5.38$ $\mathrm{mg} / \mathrm{d} l$ と高值を示したが，妊娠 35 週では $30 \pm$ $7.52 \mathrm{mg} / \mathrm{d} l$ と低下し, 分婏前に比して分婏直後 はやや增量を示した。Cī-INA 值は，妊娠初期 で $20 \mathrm{mg} / \mathrm{d} l$ 以上であり, 妊娠 18 週ごろよりそれ 
以下となり，それが妊娠40週まで持続したもの の, 分婏前後では変動を示さなかった(図 3). すなわち，プレカリクレインの増量する時期に Cì-INA は減少傾向を示した。

\section{結 論}

妊娠分娩時のプレカリクレイン・カリクレイ ン動態は，抢互い相反する傾向を示し，陣痛発 来をきたすキニン産生増量や局所的な子宮一胎 盤間の凝固線溶動態とも関連するように考えら れる。

\section{文献}

1）相馬広明，他：胎盤における Inhibitors の意 義. J. Med. Enzym., 3；67〜75, 1981.

2）相馬広明：胎盤剝離異常による出血. 産婦人 科 Mook, No. 11, 182 190, 1980.

3）福武勝博，加藤正俊：発色性合成ペプチド基 質による血液凝固線溶系因子の測定一とくに Testzym 法について一. Pure Chemicals Daiichi, 9; 87〜100, 1978.

\section{一内科と眼科の統合による成果! 糖尿病性紸膜症}

編集 東北大学内科教授 後藤由夫

琉球大学眼科教授 福田雅俊

専門医37氏分担執筆

A 5 判 355頁 図92 表86 原色10 定価7,800円(干200円)

今世紀初頭，糖尿病は死の病気であったが，インスリンや抗生物質が発見されて，寿命は飛 躍的に延長した。しかし，寿命の延長によって新たな問題が起こってきている。それは慢性合 併症（眼・腎・神経障害など）である。とくに糖尿病性網膜症による失明は近年大きな問題と なり，世界的に大規模な研究が進められている。ここに内科，眼科の専門医が従来の研究をま とめ, 治療法, 発症の防止法を一書に論じたのが本書である。

○内容：第 1 章 糖尿病性網膜症の頻度，第 2 章 網膜症忠者にみられる病態，第 3 章 内科的諸条件と網 膜症の発生と進展, 第 4 章 糖尿病性網膜症の分類, 第 5 章 糖尿病性網膜症の診断と子後, 第 6 章 糖尿 病性網膜症の発生病理, 第 7 章 眼局所状態と網膜症との関係, 第 8 章 糖尿病患者の網膜電図, 第 9 章 Diabetic maculopathy の実態について, 第10章 糖尿病の治療と網膜症, 第11章 糖尿病性網膜症の内科 的治療, 第12章 糖尿病性網膜症による視覚障害者のリハビリテーション，第13章 網膜光凝固療法による 網膜症の治療。 